\title{
BALANCING THE HIGH TECH AND HIGH TOUCH IN EDUCATION: THE IMPLEMENTATION OF HUMANISTIC APPROACH ON EDU-RECREATION CONCEPT IN POLITEKNIK PARIWISATA BALI
}

\author{
Ida Bagus Putu Puja ${ }^{1}$, Putu Ayu Aryasih ${ }^{2}$, Desak Gede Chandra Widayanthi1 ${ }^{3}$ \\ Politeknik Pariwisata Bali, Indonesia \\ ayuaryasih@ppb.ac.id
}

\begin{abstract}
The implementation of a humanistic approach in educational institutions could be guidance in balancing High Tech and High Touch. The humanistic approach is defined as a physical and spiritual activity to maximize the development process, as well as an effort to master the treasures of knowledge in a series of overall personality formations. This research is qualitative research that analyzes the application of the humanistic approach in the design of the Edu-Recreation concept at the Bali Tourism Polytechnic (Politeknik Pariwisata Bali) through the study of documents and other literature, and also observation and interview. The results of the research are proposed as input for developing existing designs so that they can have a more significant influence in improving the quality of education at the Bali Tourism Polytechnic. As the result, the Edu-Recreation concept design at the Bali Tourism Polytechnic has implemented values in the humanistic education approach, namely the development of the affective aspects of students and the freedom to develop self-potential.
\end{abstract}

Keywords: Humanistic approach, vocational education, character education

\section{INTRODUCTION}

Education is a process of humanizing humans. Further than a process of knowledge transfer, in broader concept education should enabling humans to shift from unconscious to conscious state, which means to understand the meaning and value of themselves as thinking creatures (Yanasari, 2016a). Thus, learning is not only about the transfer of knowledge, but also the transfer of value, to enable students to give and becoming the solution, and also to enable them to adapt to their environment.

The Education Commission's Learning Generation study (Lee \& Steer, 2019) issued a sobering warning: if nothing changes, 825 million young people approximately half of today's youth - would enter adulthood without the skills they require to succeed by 2030. According to Lee \& Steer (2019), the 2018 World 
Development Report from the World Bank reiterated a similar warning, describing the global learning problem as a "moral catastrophe." World Development Report on The Changing Nature of Work urged governments to "invest with a strong sense of urgency in education and health to harness the advantages of technology and to mitigate its worst disruptions."

In accordance with the problem mentioned by Lee \& Steer (2019), Indonesia is also facing complex problems in education. Some of them are curriculum development and policy, quality management and standardization, and leaders' competency (Nasution, 2008). In the globalization era which demands high technological and professional skills, and the ability to adapt to a dynamic working environment, the value of education is shifting to High Tech (high technology). An educational system that values the high-tech would engage the development of cognitive areas of the students, meanwhile, education itself is a process of knowledge transfer and value transfer that only be possible happen in the balance between High Tech and High Touch. The value of High Tech would develop humans with high professional skills to fulfill their life needs, while the value of High Touch world enable them to be conscious of their human needs to collaborate with their environment, to solve community problems, and to value the sense of humanity Dimoff (2017).

To respond the issue, the implementation of the humanistic approach in the educational institution could be guidance in balancing the High Tech and High Touch in learning process. High Tech and High Touch based on Dimoff (2017), is about consciously integrating technology into our daily lives. Moreover, it is stated that the approach is about embracing technology that retains our humanness while rejecting technology that intrudes on it. To put it another way, our relationship with technology must be balanced. According to Prayitno (2017), the up-righting of two pillars, namely high touch and high tech pillars, results in teaching-learning processes that are full of character values. To begin with, the high touch pillar fosters a good and progressive social-personal interaction between students and instructors, as well as among students themselves. Teachers or educators operate the five important elements, namely: (1) acknowledgment and acceptance, (2) love and compassion, (3) reinforcement, (4) firmness with good values and no punishment, and (5) guidance and example, inside their high touch action. The high touch pillar places students in a lovely, warm, and positive setting, i.e. feeling friendly, free to express oneself, open connection yet normative, dynamic, and progressive, and opened the possibility for students to give and receive something good. Second, the high-tech pillar is concerned with the substance and technology of teaching-learning activities. There are five other significant points within the high tech pillar, namely (1) the acquisition of teaching-learning materials by teachers or educators, (2) the application of teaching technologies, (3) the benefiting teaching aids, (4) the arrangement of teaching-learning environment, and (5) the application of evaluation and follow up of teaching-learning results.

Lee \& Steer (2019) suggests that High Tech learning could allow the students to master the lower level competence in Bloom's taxonomy, while the higher-level competencies would be achieved through High Touch learning provided by the teacher's presence and sufficient learning environment. This explanation is presented in Figure 1. 


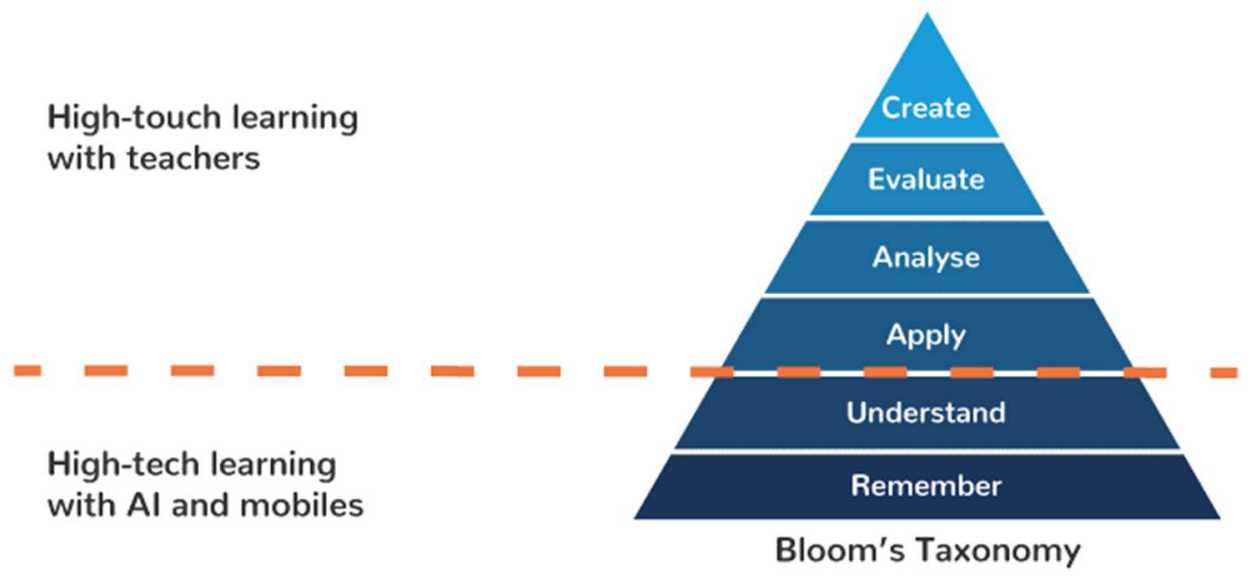

Figure 1. High-Touch and High-Tech Learning Applied on Bloom's Taxonomy (Lee \& Steer, 2019)

The approach is defined as a physical and mental activity to optimize the development of knowledge and character. The development happens only if the learning process exists as habit and ability (Sumantry \& Ahmad, 2019). The meaning of the humanistic approach as an effort to develop humans' potentials holistically, the humanistic approach could be implemented to balance the High Tech and High Touch.

Suriyadi and Suryasih (2018) in their research of the utilization of Lumintang City Park and the significance of recreation mentioned that the youth are known to have various activities in their daily lives. a lot of them needed the time to clear their mind from the stress. Many teenagers visit the Lumintang City Park during their spare time to recharge and reinvigorate their energy with various recreational activities. The main purpose of conducting this study is to ascertain the utilization of Lumintang City Park and the significance of recreation obtained by the youth following their recreational activities at Lumintang City Park. Data were collected through observation and questionnaire, and to determine sample using the quota sample to the tune of 50 respondents. The result of the conducted study had shown that Lumintang City Park is utilized by the youth as a place to exercise, lounge around, enjoy the evening atmosphere, cure boredom, and many other activities, with a relatively dominating advantage specifically in the utilization of Lumintang City Park as a place to exercise. Moreover, the significance of the recreation obtained by the youth in the wake of their activities at Lumintang City Park is dominated by recreation and well-being.

To implement the humanistic approach in providing education at Politeknik Pariwisata Bali (Bali Tourism Polytechnic), the concept of Edu-Recreation was designed as the new idea. This concept emphasizes the importance of developing affective aspects in education by developing a pleasant campus design and having facilities that open opportunities for students to develop their full potential.

This research is qualitative research that analyzes the application of a humanistic approach in the design of the Edu-Recreation concept at the Bali 
Tourism Polytechnic through the study of documents and other literature. The results of the research are proposed as input to develop existing designs so that they can have a more significant influence in improving the quality of education at the Bali Tourism Polytechnic

\section{METHODOLOGY}

This research was conducted by conducting a literature review, observation, and interview with the related stakeholders. Data were collected qualitatively from literature studies in the form of empirical studies, documents, and books, observation at Bali Tourism Polytechnic, and interviews with related stakeholders, such as the students, management of the school, former leaders, and lecturers. The data were then analyzed and described qualitatively. The research was conducted at the Bali Tourism Polytechnic, which is a state tourism polytechnic under the Ministry of Tourism and Creative Economy of the Republic of Indonesia. The result of the study would be a recommendation for the related stakeholders of the school to ensure the further development could facilitate an educational system that is in line with the humanistic approach.

\section{RESULTS AND DISCUSSION}

Based on the humanistic approach, the learning process begins and ends with humans themselves. This theory emphasizes the ideal conditions of education whose goal is to humanize humans (Yanasari, 2016b). The humanistic approach views that all students basically have good basic characteristics and are motivated to actualize these basic properties. In the actualization process in question, environmental factors play a very important role. A positive environment can create conditions for students to be able to actualize themselves well (Nursanjaya, 2020). Humanistic education focuses on respecting human rights, including the freedom to express oneself, think critically, and act in accordance with noble values and humanitarian norms. Thus, education is essentially a process of humanization (humanizing), implying that education is the foundation for the formation of human personality (Firdaus \& Mariyat, 2017). According to Umar (2018), the development of an affective education model rests on three things, namely self-awareness as a growth process that is and will continue to change, recognizing self-concept and identity, and integrating awareness of the heart and mind. The majority of important features of humanism, according to Stevick (1980, as cited in Prabhavathy \& Mahalakshmi 2016), include feelings, personal, emotional, and creative admiration, while social relationships include the side of humanism that promotes intimacy and partnership, and intellect relates knowledge, reason, and understanding with selfactualization.

In the humanistic approach, three learning models are formulated, namely open education, confluent education, and cooperative learning. Open education is an educational process that provides opportunities for students to move freely around the classroom and in choosing the learning activities to be followed. In 
addition, the hallmark of the implementation of open education is the availability of facilities that allow students to freely develop their potential. Confluent education is a learning process that combines and brings together affective experiences in learning, such as through story-reading activities, sociodrama, listening to stories, listening to music, watching movies, conducting volunteer activities, and carrying out case studies. Cooperative learning has the main characteristic of carrying out learning in group activities. Group activities are encouraged in the formation of groups with members who have different abilities or characteristics. Students are encouraged to help each other in studying the same material so that success is seen from the success of the group, not the individual (Setiawati, n.d.).

The Edu-Recreation concept is designed to improve the quality of learning at Bali Tourism Polytechnic. Edu-Recreation comes from two words, namely "education" and "recreation". As the name implies, the concept of Edu-Recreation is an "enjoyable" campus design, so that apart from being a place for studying (cognitive) and developing skills (psychomotor), the campus is designed to be a good place for recreation for students' affective conditions. The Edu-Recreation concept broadly involves the development of three campus components, namely physical facilities, curriculum, and services.

In the development of physical facilities, the Edu-Recreation concept directs the development of facilities that are comfortable, beautiful, and can facilitate the development needs of students' potential and character. The monumental development of physical facilities is shown in Figure 2.

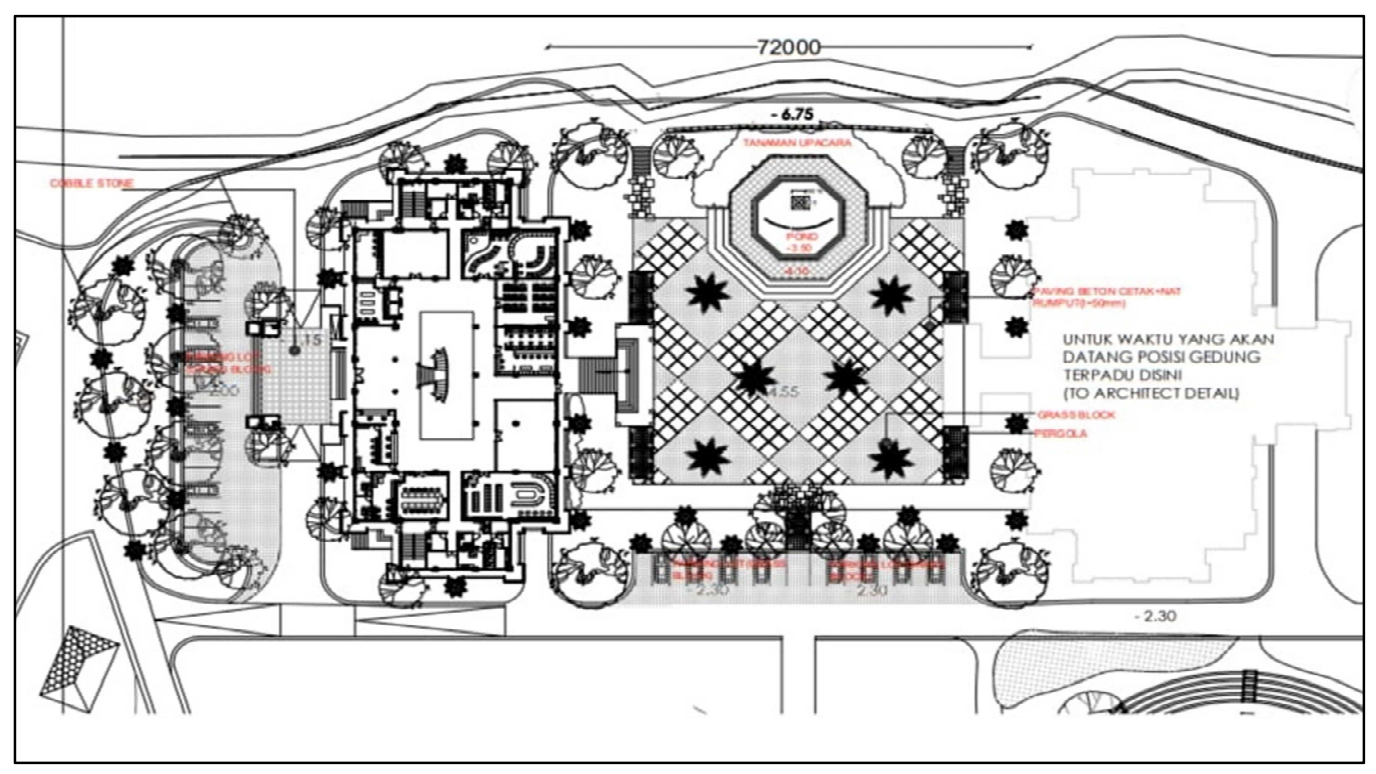

Figure 2. Site Plan of Physical Facilities Development at Bali Tourism Polytechnic

As stated by Nursanjaya (2020), the implementation of the humanistic approach has to be supported by an environment that facilitates the development of affective aspects and the development of students' potential. According to 
Prabhavathy and Mahalakshmi (2016), the educational and learning process has four perspectives: "Educator," "Student," "Learning Procedure," and "Learning Situation." Although the four perspectives shown above are typical of a teaching and learning situation, there are significant differences in educational and learning levels. Education is more effective when teachers provide a positive personal image while organizing effective contextual assignments and creating a supportive environment. Moreover, according to Arifi (2017), the ultimate goal of humanistic education is to create a trustworthy cultured society that embraces diverse cultures. The humanistic method begins with the ideas that form the basis of an educational experience. A humanistic viewpoint supports the idea that educational value is diminished if the process of learning and the environment in which learning happens is ignored. In today's society, the emphasis has shifted away from academic achievement and toward self-actualization.

In the construction of the physical facilities of the Bali Tourism Polytechnic with the concept of Edu-Recreation, the main priority components for development are the development of landscape and comfortable facilities for students to study outside the classroom, as well as the inclusion of local cultural values in the provision of campus facilities. The campus landscape with the inclusion of local cultural values is designed to become a living museum as well as a learning tool for all academics. Landscape in this case could function more than just as a green park that beautifies the environment, but also as a learning facility for the tourism campus which is developed as a center of excellence in cultural tourism. The green park as a humanistic learning facility is shown in Figure 3. 


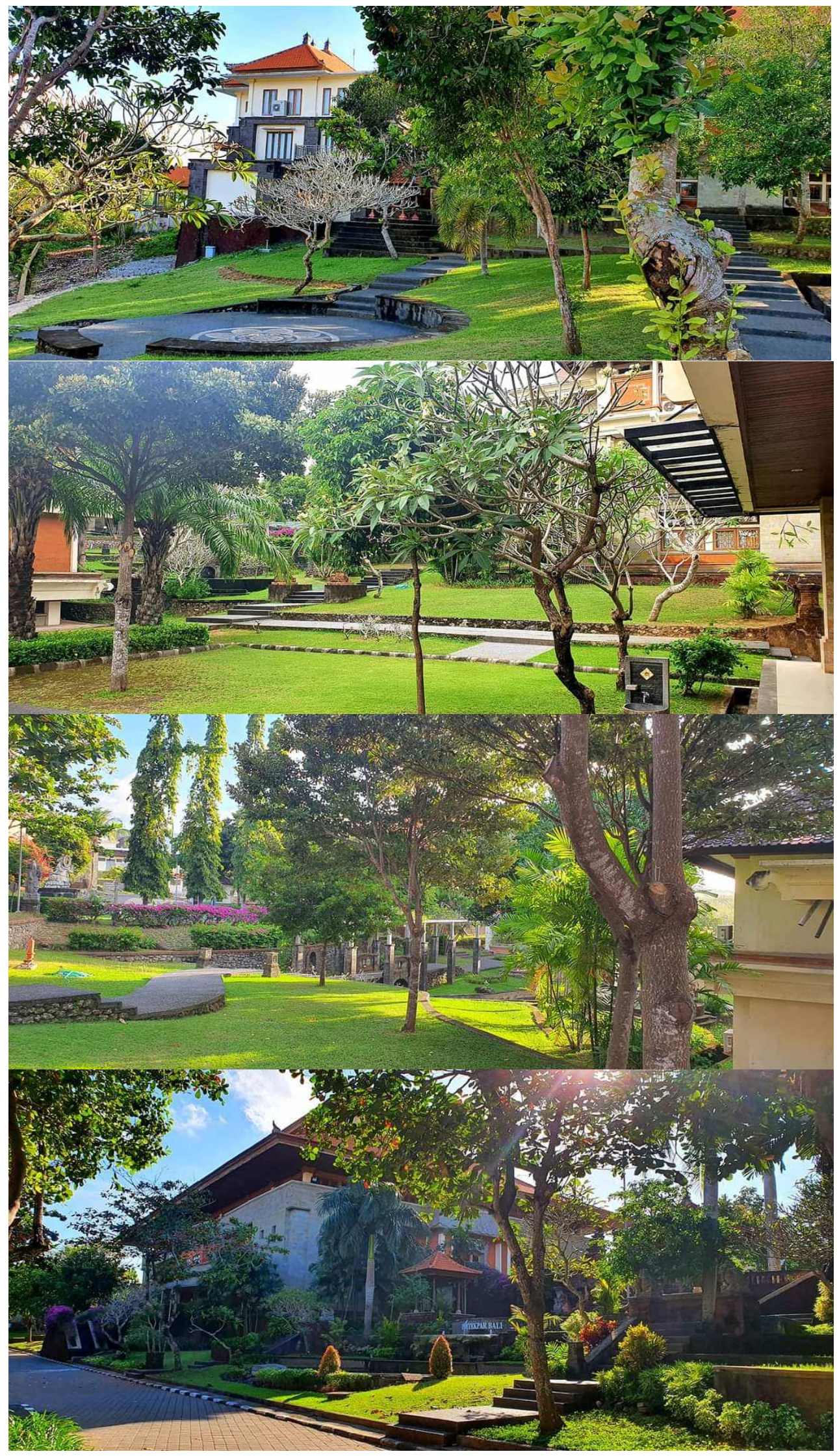


Figure 3. Green Environment as a Humanistic Learning

Local cultural value that contan t lot. of local wisdom and local genius could be a supplement to shape students character. The landscape components being mentioned are:

a) The landmark of the 7 meters Saraswati statue is a symbol of science as the movement of humans from being unaware of their nature as humans to the state of beings' consciousness. Saraswati, the Goddess of Knowledge, is shown as a lovely lady with four hands riding on a white swan among water lilies to remind humanity that science is similar to a beautiful woman. A palm leaf, a lontar (a Balinese traditional book that is the source of science or knowledge), a chain (genetic with 108 pieces) symbolizing that knowledge is never-ending and has an everlasting life cycle, and a musical instrument (guitar or wina) symbolizing that science develops through the growth of culture are all held in her hands. Swans represent wisdom, allowing one's understanding to differentiate between good and evil, while water lilies (Lotus) represent holiness. The Lotus flower is considered to be the holiest of all flowers (Foley, 2016).

b) Manganjali Karya Werdhi Park with terraces symbolizes the journey of life that goes uphill, that in life there needs to be struggle and dedication to achieve glory.

c) Watugunung Amphitheatre which fragments the mythical legend of Watugunung and the 27 kingdoms that underlie the philosophy of Saraswati.

d) The statue of Pancanaka, which symbolizes the incarnation of Lord Vishnu in the form of a turtle with a nail weapon that succeeded in conquering King Watugunung. This is related to the legend behind the birth of Saraswati's philosophy.

The landscape arrangement of the Bali Tourism Polytechnic campus environment with statues symbolizing the characters in Balinese legends full of local genius values is provided as peripheral learning media. Peripheral Learning is a learning strategy introduced by Georgy Lozanov in 1978. This learning strategy is based on the human ability to learn from the environment unconsciously or acquiring (Tyas, 2019). Peripheral learning is based on the subconscious human ability to learn and instill an understanding of a value through continuous exposure to information in the environment (Demirağ, 2018). The selection of characters displayed through statues and the concept of garden arrangement is based on the institutional core values of the Bali Tourism Polytechnic which is closely related to the legend of Saraswati. Through these statues as peripheral learning media, it is expected that there will be an instillation of the institution's core values into the realm of sub-conscious academics, namely learning values which are interpreted not only as a process of studying but also a process of growing awareness according to the nature of oneself as a civilized human being.

The Edu-Recreation concept is designed to facilitate the different interests and talents of Bali Tourism Polytechnic students. To facilitate this diversity, various extracurricular activities in academic and non-academic fields are provided. Students are given the freedom to choose the extracurricular they are interested in. 
Moreover, the campus environment is designed with a variety of learning situations in mind. In addition to classroom learning, learning facilities are provided in laboratories, libraries, open parks, and indoor internet rooms. Students can choose their study location for their convenience. From this explanation, the EduRecreation concept design fulfills the principles of implementing a humanistic approach in education, namely facilitating the development of students' affective aspects and freedom in developing students' interests and talents (Setiawati, n.d.). The relationship between the Edu-Recreation concepts at the Bali Tourism Polytechnic with the Humanistic approach is illustrated in Figure 2.

Furthermore, the humanistic approach in the design of the Edu-Recreation concept is also applied in the design of extra-curricular programs for students. Extracurricular programs are designed with a wide range of choices to facilitate the diversity of interests and talents of students. As stated by Frias (2019), the humanistic method emphasizes the learner's unique liberty, preferences, inspiration, self-determination, and personal goals (Woolfolk, 2008). For this approach to progress, the learners must be provided with a secure learning environment that is built on empathy, kindness, and the teacher's acceptance of diverse points of view. The instructor acts as a facilitator in this technique, while the student is in charge of their education (Bentham, 2002). Extracurricular program options are presented in Table 1 and the activities of extracurricular programs are presented in Figure 4.

Table 1. Extra-Curricular Programs in Bali Tourism Polytechnic

\begin{tabular}{ll}
\hline Academics & Non-Academics \\
\hline France club & Balinese Music Ensemble \\
Japanese club & Volleyball \\
Scientific Writing & Table Tennis \\
Journalism & Basket Ball \\
Juggling & Futsal \\
Making bed & Soccer \\
Barista & Music Band \\
Chef & Choir \\
Food and ice carving & Marching band \\
& Yoga \\
& Chess \\
\hline
\end{tabular}
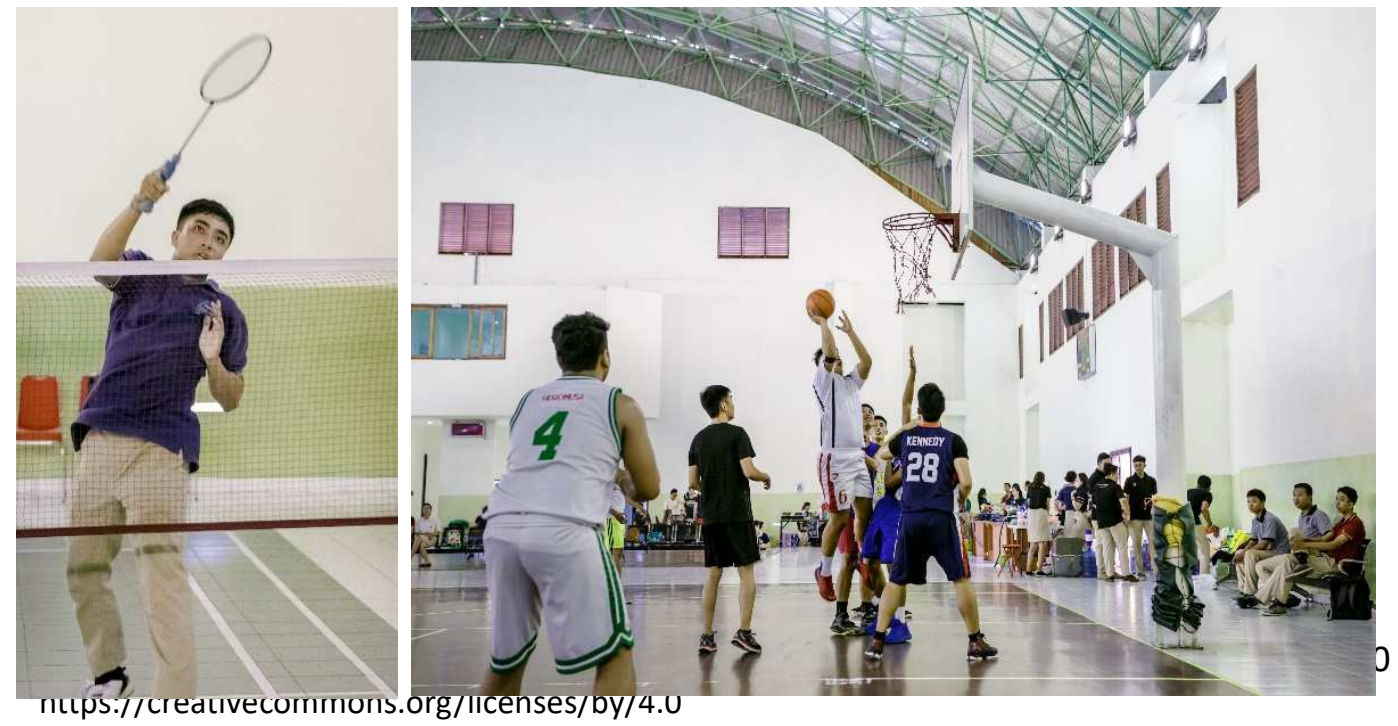

Figure 4. Activities of Extracurricular Programs (Pictures were taken before the Covid-19 Pandemic) 
As expressed by (Setiawati, n.d.), in the humanistic approach, three learning models are formulated, namely open education, confluent education, and cooperative learning. Open education provides opportunities for students to move freely around the classroom and in choosing the learning activities to be followed, with the main characteristic that the school has sufficient availability of facilities that allow students to freely develop their potential. Confluent education is a learning process that combines and brings together affective experiences in learning. Cooperative learning has the main characteristic of carrying out learning in group activities so that success is seen from the success of the group, not the individual. The Edu-Recreation concept design at the Bali Tourism Polytechnic is a combination of open education and confluent education, which facilitates freedom of learning within the limits of the curriculum of the study program, freedom to move in a comfortable space outside the classroom, and the existence of affective experiences in learning inside and outside the classroom.

To balance the High Touch, the school is also supporting students' learning by providing High Tech facilitation. All classrooms are provided with a large LED Screen for displaying learning media. High-speed free Wi-Fi could be accessed at all campus areas. The laboratories are equipped with high-tech facilities to support the learning. One of them is the Meeting, Incentive, Conference, and Events laboratory (Figure 5).
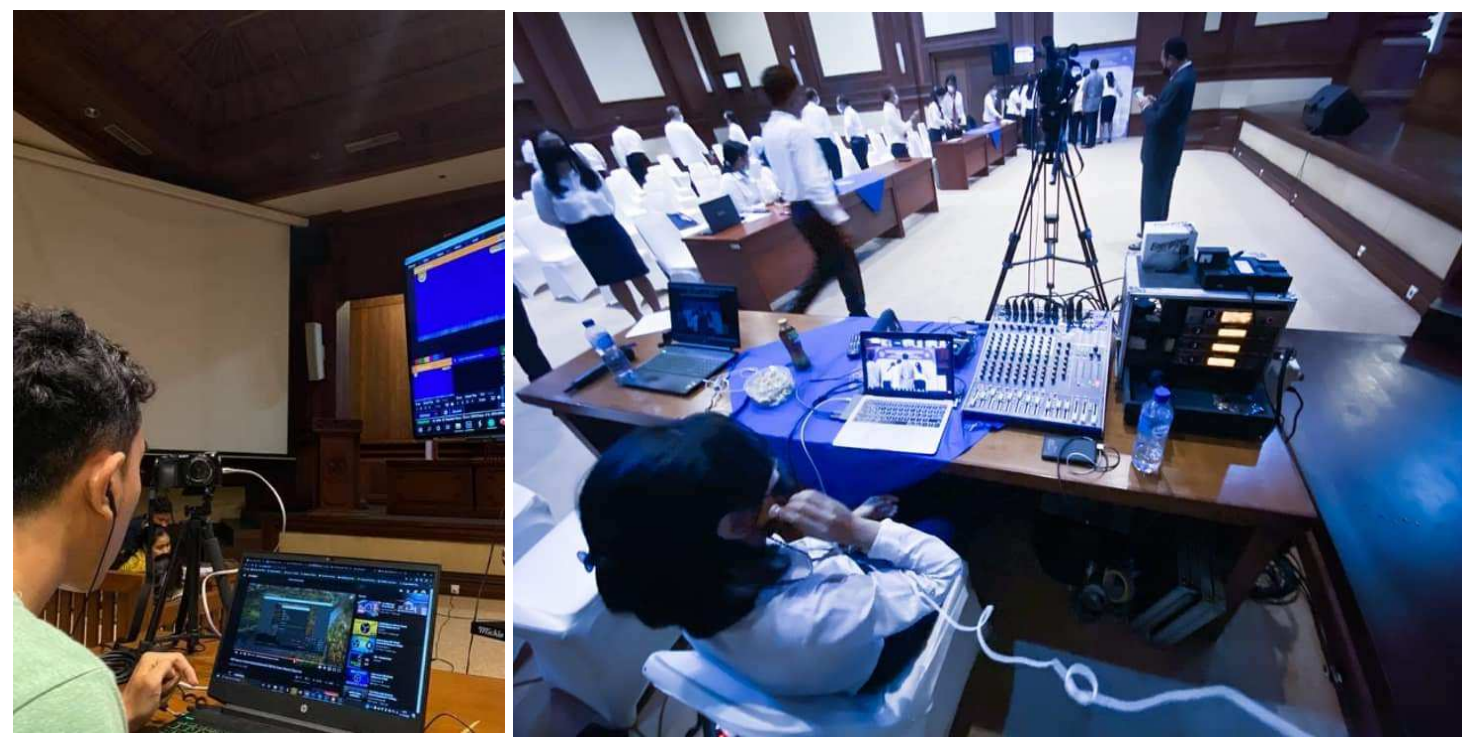

Figure 5. Meeting, Incentive, Conference and Events (MICE) Laboratory (Pictures were taken before the Covid-19 Pandemic)

The school has been conducting online learning due to the Covid-19 
pandemic by using web-based online meeting applications such as Zoom, school's web-based e-learning application, and Google Meet. However, some areas are still needed to be developed, such as the e-learning effectiveness, technology in the vocational laboratories, and the use of e-library. For further development, it is planned to improve the system to be an integrated system that includes the academic service and information system, e-learning, and e-library.

The concept of Edu-Recreation is suitable to be applied at the Bali Tourism Polytechnic considering the affective development of Bali Tourism Polytechnic students to become graduates is very important to achieve. As stated in Peraturan Menteri Pariwisata dan Ekonomi Kreatif Nomor 4 Tahun 2020 tentang Statuta Politeknik Pariwisata Bali (an official law issued by the Ministry of Tourism and Creative Economy of the Republic of Indonesia about the Statute of Bali Tourism Polytechnic), the vision of Bali Tourism Polytechnic is to become an excellent tourism higher vocational school with international standard and Indonesian characters. The vision statement leads the school to engage human resource development with high competitiveness in tourism vocational skills and also excellent personal characters in accordance with Indonesian cultural values.

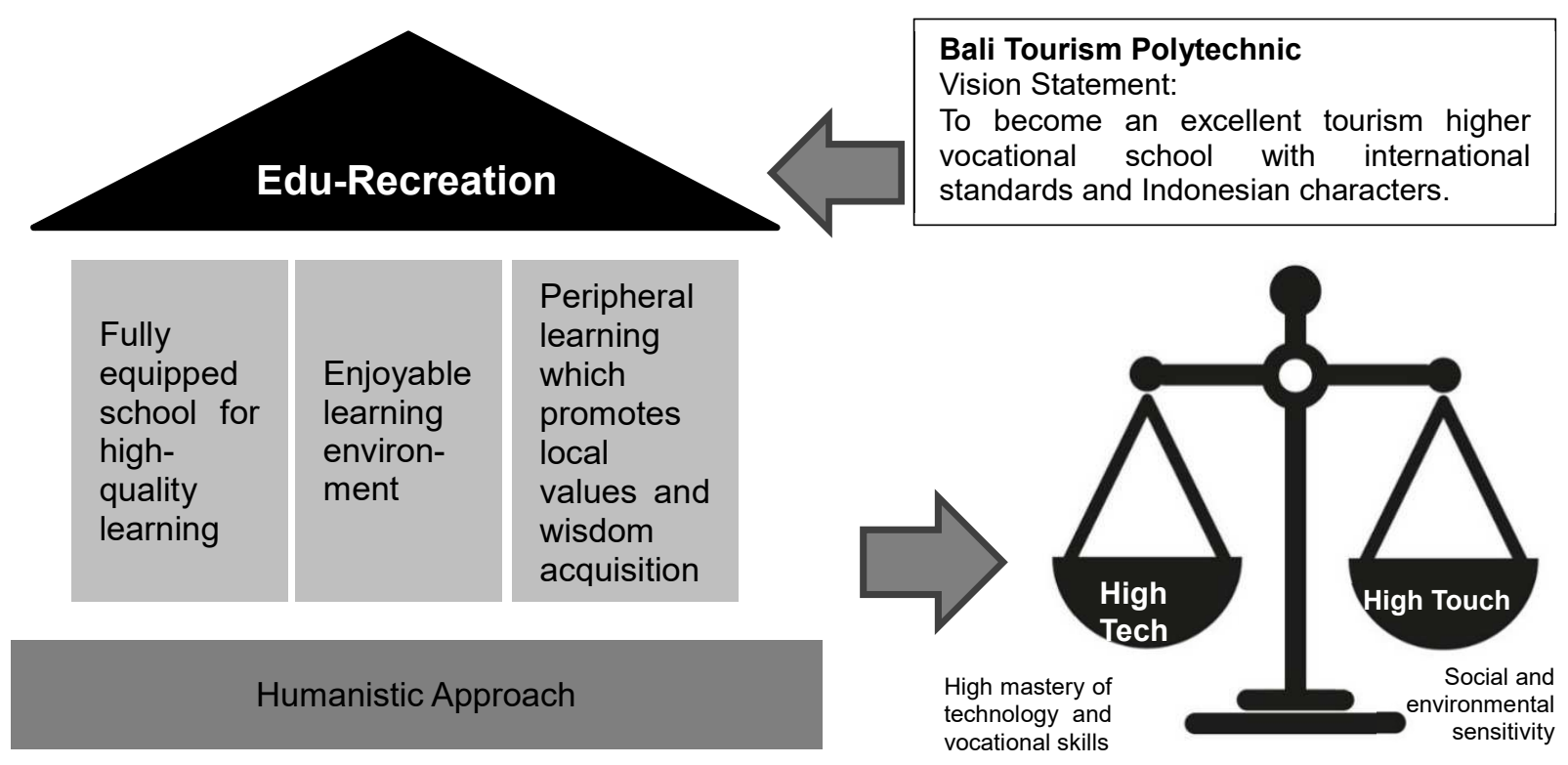

Figure 6: Relationship Between Vision Statement, Edu Recreation Concept, Humanistic Approach, and the Balance of High Tech and High Touch

Graduates are projected to work as practitioners and academics in the field of tourism and hospitality. In this area, a service industry focuses on creating pleasure (leisure) for clients, in this case, tourists. Practitioners and academics in this field are important to have a high sense of service so that there is no burden in providing services by prioritizing client satisfaction without forgetting the existing code of ethics. 


\section{CONCLUSION AND RECOMMENDATION}

Based on the explanation and analysis, it can be concluded that the concept of Edu-Recreation at Bali Tourism Polytechnic has implemented values in the humanistic education approach, namely the development of students' affective aspects and the freedom to develop self-potential. The development of affective aspects is realized through the provision of comfortable and enjoyable learning facilities indoors and outdoors and the provision of symbols of local genius which are peripheral learning media. The freedom to develop self-potential is realized through the provision of various extra-curricular activities that facilitate the diversity of interests and talents and the provision of various learning facilities outside the classroom as well as sufficient space for socializing.

Due to the findings, it is suggested to conduct further development in the aspects of High Tech. This is to ensure the school is able to facilitate the learning process with enough technology which is rapidly developed nowadays. The development should also include the development in human capability to master the high-tech tools. Moreover, the concept of Edu-Recreation could be recognized as a new concept as there are not many studies mentioned about it yet. Thus, it is suggested for the school to take this concept as a unique point, and as the company value for the basis of further development.

\section{REFERENCES}

Arifi, Q. 2017. Humanistic Approach in Teaching Foreign Language (from the Teacher Perspective). European Scientific Journal. 13(35), 194-20.

Bentham,S. 2002.Psychology and Education East Sussex: Routledge. https://www.taylorfrancis.com/books/9781134587483.

Demirağ, N. B. 2018. Peripheral Learning and Its Effectiveness in Intensive English Classes.

Dimoff.T. 2017. High Tech Vs. High Touch: Balancing Technology and People. Retrieved from https:/www.cose.org/en/Mind-YourBusiness/Operations/High-Tech-Vs-High-Touch-Balancing-Technologyand-People on 30 August 2021.

Firdaus, Fauzan \& Mariyat, Akrim. 2017. Humanistic Approach In Education According To Philosophy of Education. T\&L cert. John Wiley and Sons 1(1), 1-5.Paulo Freire. At-Ta'dib. 12. 25. 10.21111/at-tadib.v12i2.1264.

Foley, Kathy. 2016. Saraswati in Bali: A Temple, A Museum, and A Mask by Ron Jenkins. Asian Theatre Journal. 33. 516-517. 10.1353/atj.2016.0042.

Frias, J. 2019. Improving learning experiences by using Humanism and Constructivism teaching approaches in the classroom.

Kementerian Pariwisata dan Ekonomi Kreatif Republik Indonesia. 2020. Peraturan Menteri Pariwisata dan Ekonomi Kreatif Nomor 4 Tahun 2020 tentang Statuta Politeknik Pariwisata bali. Jakarta: Direktur Jenderal Peraturan Perundang- 
Undangan Kementerian Hukum dan Hak Asasi Manusia Republik Indonesia.

Lee, J.H. \& Steer, L. 2019. Combining High-Tech and High-Touch to Personalize Learning for Every Child. Retrieved from https://www.theewf.org/research/2019/combining-high-tech-and-high-touchto-personalize-learning-for-every-child on 30 August 2021.

Mei Ardaning Tyas. 2019. The Effectiveness Of Activating Students' Peripheral Learning Strategy On Teaching Descriptive Text Writing For The Tenth Graders In Sma Negeri 1 Nganjuk.

Nasution, E. 2008. Problematika Pendidikan di Indonesia. Jurnal Fakultas Ushuluddin dan Dakwah IAIN Ambon, 1-10.

Nursanjaya. 2020. Aplikasi Teori Humanistik Perguruan, Interaksi DosenAmahasiswa di Tinggi. NEGOTIUM: Jurnal Ilmu Administrasi Bisnis, 3(1), 23-38.

Prabhavathy. P. \& Mahalakshmi S. N. 2012. ELT with specific regard to humanistic Approach. IOSR Journal of Humanities and Social Science, Volume 1, Issue 1, PP 38-39.

Prayitno. 2017. Character, The Total Dimension Of Education. SCHOULID: Indonesian Journal of School Counseling. 4(3),60-64.

Setiawati, F. A. n.d. Pendekatan Humanistik Dalam Bimbingan. 45-58.

Sumantri, B. A., \& Ahmad, N. 2019. Teori Belajar Humanistik dan Implikasinya terhadap Pembelajaran Pendidikan Agama Islam. Fondatia, 3(2), 1-18. https://doi.org/10.36088/fondatia.v3i2.216

Umar, M. 2018. Pendekatan Humanistik dalam Proses Pembelajaran Program Pendidikan Kesetaraan Paket C. Jurnal Pendidikan Nonformal, 13(2), 70-77.

Woolfolk, A. 2008. Educational Psychology (10th Ed.). USA: Person Education Inc. https://www.pearson.com/us/highereducation/product/WoolfolkEducational-Psychology-Active-Learning-Edition-10th-

Edition/9780205542789.html

Yanasari, P. 2016a. the Humanistic Approach To Change and the Development of Behavior. IX(2), 159-167.

Yanasari, P. 2016b. The Humanistic Approach to Change and The Development of Behavior in The Realm Of Education. NUANSA, Vol. IX,(2), 159-165. 